\title{
Characterization of the Mycobacterium tuberculosis erp gene encoding a potential cell surface protein with repetitive structures
}

\author{
François-Xavier Berthet, ${ }^{1}$ Jean Rauzier, ${ }^{1}$ Eng Mong Lim, ${ }^{1}$ \\ Wolfgang Philipp, ${ }^{2}$ Brigitte Gicquel' and Denis Portnor ${ }^{1}$
}

Unité de Génétique Mycobactérienne (CNRS, URA 1300) ${ }^{1}$ and Unité de Génétique Moléculaire Bactérienne2, Institut Pasteur, 25 rue du Dr Roux, 75724 Paris Cedex 15 , France

\author{
Author for correspondence: Denis Portnoï. +331456888 40. Fax: + 33145688843 . \\ e-mail:dportnoi@pasteur.fr
}

\begin{abstract}
Using the phoA gene fusion methodology adapted to mycobacteria, several Mycobacterium tuberculosis DNA fragments encoding exported proteins were recently identified. In this paper, the molecular cloning, genomic positioning, nucleotide sequence determination and transcriptional start site mapping of a new $M$. tuberculosis gene, identified by this methodology, are reported. This gene was called erp (for exported repetitive protein) and has a sequence similar to that of the Mycobacterium leprae $28 \mathrm{kDa}$ antigen irg gene M. tuberculosis erp gene contains a putative iron box close to the mapped transcriptional start site. The predicted Erp protein displays a typical $\mathbf{N}$-terminal signal sequence, a hydrophobic domain at the C-terminus and harbours repeated amino acid motifs. These structural features are reminiscent of cell-wall-associated surface proteins from Gram-positive bacteria. We found that these repeats are conserved among $M$. tuberculosis isolates, and are absent from the published $M$. leprae ing gene sequence. In addition to being present in $M$. leprae, erp sequences were found in other members of the $M$. tuberculosis complex, but not in other mycobacteria tested. These results suggest that erp might encode a cell surface component shared by major pathogenic mycobacteria.
\end{abstract}

Keywords: Mycobacterium tuberculosis, erp, exported repetitive protein

\section{INTRODUCTION}

Mycobacterium tuberculosis and Mycobacterium bovis, the etiologic agents of tuberculosis, are facultative intracellular bacteria. The ability to invade, survive and multiply within macrophages contributes to their pathogenicity. For other intracellular bacterial pathogens, proteins compartmentalized on the outer surface mediate the interaction with the host cells. Examples include the $103 \mathrm{kDa}$ invasin of Yersinia pseudotuberculosis (Isberg et al., $1987)$ or the $80 \mathrm{kDa}$ internalin from Listeria monocytogenes (Gaillard et al., 1991). Similarly, proteins exported by pathogenic mycobacteria are likely to be involved in the infection of macrophages and intracellular survival.

The adaptation to $M$. tuberculosis of a genetic methodology for the identification and phenotypic selection of exported

Abbreviation: PhoA, alkaline phosphatase.

The GSDB accession number for the sequence reported in this paper is L38851. proteins was recently described by Lim et al. (1995) and Timm et al. (1994). This method uses the Escherichia coli periplasmic alkaline phosphatase (PhoA) (Hoffman \& Wright, 1985; Manoil et al., 1990) as a heterologous reporter for exportation in mycobacteria. A plasmid vector allowing gene fusions between a truncated $p b 0 \mathrm{~A}$ gene and mycobacterial genomic DNA was constructed and used to select translational fusions with PhoA activity. Using this system, a $M$. tuberculosis DNA fragment showing sequence similarities with a Mycobacterium leprae gene (irg) encoding a $28 \mathrm{kDa}$ exported protein antigen (Lim et al., 1995; Cherayil \& Young, 1987), was identified. This $M$. leprae protein has been previously reported to be a major target of the humoral immune response in the lepromatous form of leprosy. The predicted protein sequence contains a potential signal peptide at its amino terminus and two long hydrophobic domains, suggesting that it might be targeted for localization across the bacterial plasma membrane or the cell wall. The corresponding gene was referred to as the iron-regulated gene (irg), because a potential iron box is present in the 
regions likely to control its expression (Dale \& Patki, 1990; Young et al., 1992). The M. tuberculosis gene, like the $M$. leprae irg gene, encodes an exported repetitive protein and is called erp. In this paper we report the cloning, genomic positioning, nucleotide sequence determination, distribution among mycobacterial species and transcriptional start site mapping of the complete $M$. tuberculosis erp locus.

\section{METHODS}

Bacterial strains, plasmids and culture media. The bacterial strains and plasmids used in this work are listed in Table 1. E. coli and Mycobacterium smegmatis were grown routinely on solid or liquid Luria Bertani (LB) medium (Miller, 1972). For RNA isolation, $M$. smegmatis cultures were grown in Middelbrook $7 \mathrm{H} 9$ liquid medium (Difco) supplemented with glycerol $(0 \cdot 2 \%)$. Transformants were selected and plasmids were maintained on media containing $100 \mu \mathrm{g}$ ampicillin $\mathrm{ml}^{-1}$ or $20 \mu \mathrm{g}$ kanamycin $\mathrm{ml}^{-1}$. PhoA activity was detected on LB plates containing 5bromo-4-chloro-3-indolyl phosphate $\left(40 \mu \mathrm{g} \mathrm{ml}^{-1}\right)$.

PCR conditions and primers. All PCR amplifications were performed in a final volume of $100 \mu \mathrm{l}$ containing $50 \mathrm{mM} \mathrm{KCl}$, $10 \mathrm{mM}$ Tris/ $\mathrm{HCl}, \mathrm{pH} 8 \cdot 3,1.5 \mathrm{mM} \mathrm{MgCl}_{2}, 0.01 \%$ (w/v) gelatin, $20 \mu \mathrm{M}$ of each dNTP, $0.2 \mathrm{mM}$ of each primer, $10 \%(\mathrm{v} / \mathrm{v})$ DMSO and $2 \mathrm{U} \mathrm{Taq}$ polymerase (Perkin Elmer Cetus). The 177 bp erp fragment used for Southern blotting experiments was generated by PCR amplification of nt 451-618 with 53Bw (5'GCTCTCGACAGCCATGA-3') and 53Fw (5'-GGACAACCCCTGCGATA-3') oligonucleotide primers. Oligonucleotides 53Bw2 (5'-TGACCGACCTGCCCGGC-3') and 53Fw5 (5'-GCCCAACTCGT'TGGCCACCTG-3') were used for amplifying the 539 bp fragment from various $M$. tuberculosis isolates. Both PCR reactions consisted of one cycle of denaturation $\left(94^{\circ} \mathrm{C}, 5 \mathrm{~min}\right.$ ) followed by 30 cycles of amplification consisting of denaturation $\left(94^{\circ} \mathrm{C}, 1 \mathrm{~min}\right)$, annealing $\left(55^{\circ} \mathrm{C}, 1 \mathrm{~min}\right)$ and primer extension $\left(72^{\circ} \mathrm{C}, 2 \mathrm{~min}\right)$.
DNA hybridization. For Southern blotting experiments, $10 \mu \mathrm{g}$ genomic DNA was digested with $20 \mathrm{U}$ of restriction enzymes and separated by electrophoresis through $1.0 \%(\mathrm{w} / \mathrm{v})$ agarose gels. Gels were processed and DNA was transferred to a Hybond $\mathrm{N}^{+}$nylon membrane (Amersham) as described by Sambrook et al. (1989). The DNA was immobilized by UV illumination at $365 \mathrm{~nm}$ for $3 \mathrm{~min}$. Membranes were prehybridized at $65^{\circ} \mathrm{C}$ for $2 \mathrm{~h}$ in Rapid-hyb buffer (Amersham) supplemented with denatured E. coli DNA $\left(0 \cdot 25 \mathrm{mg} \mathrm{ml}^{-1}\right.$, Sigma). The labelled probe $\left(10^{6}\right.$ c.p.m. $\left.\mathrm{ml}^{-1}\right)$ was denatured, added to the membrane and incubated at $65^{\circ} \mathrm{C}$ for $2 \mathrm{~h}$. The membranes were washed once at $42^{\circ} \mathrm{C}$ with $2 \times \mathrm{SSC}$ for low stringency conditions and three times for $10 \mathrm{~min}$ each at $65^{\circ} \mathrm{C}$ with $2 \times$ SSC, $1 \times$ SSC and $0.1 \times$ SSC for high stringency conditions.

Construction and screening of a plasmid genomic library. $M$. tuberculosis $\mathrm{Mt} 103$ genomic DNA $(3 \mu \mathrm{g})$ was digested to completion with PstI and then separated through $1.0 \%$ agarose gel. Restriction fragments ranging from 2 to $6 \mathrm{~kb}$ were excised from the gel, purified and ligated to a dephosphorylated pBluescriptII KS-vector (Short et al., 1988) linearized with PstI. The ligation mixture was used to transform E. coli XL1-Blue yielding 2000 ampicillin-resistant transformants. Plasmid DNA was prepared from ten clones and all contained an insert. Colonies were transferred to Hybond $\mathrm{N}^{+}$nylon filters (Amersham) and hybridization-screened with a $\alpha-{ }^{32}$ P-labelled 177 bp PCR fragment probe, using the conditions described above for Southern blotting under high stringency.

DNA sequencing and analysis. Sequences of double-stranded plasmid DNA were determined by the dideoxy chain-termination method (Sanger et al., 1977) using the T7 sequencing kit (Pharmacia), according to the manufacturer's instructions, or using the Taq DyeDeoxy Terminator Cycle sequencing kit (Applied Biosystems), on a GeneAmp PCR System 9600 (Perkin Elmer), and run on a DNA Analysis system model 373 stretch (Applied Biosystems). The sequence was assembled and processed using DNA strider (CEA) and the University of

Table 1. Strains and plasmids used in this study

\begin{tabular}{|c|c|c|}
\hline Strain/plasmid & Relevant characteristics & Source/reference \\
\hline \multicolumn{3}{|l|}{ Strain } \\
\hline E. coli XL1-Blue & $\begin{array}{l}\sup E 44 \text { bsdR17 rec } A 1 \text { gyrA96 thi relA1 } \\
\text { lac } \mathrm{F}^{\prime}\end{array}$ & $\begin{array}{l}\text { Sambrook et al. } \\
\text { (1989) }\end{array}$ \\
\hline M. smegmatis $\mathrm{mc}^{2} 155$ & $\begin{array}{l}\text { High-transformation mutant of } M \text {. smegmatis } \\
\text { ATCC } 607\end{array}$ & $\begin{array}{l}\text { Snapper } \\
\text { et al. }(1990)\end{array}$ \\
\hline \multicolumn{3}{|l|}{ Plasmid } \\
\hline pJEM11 & $\begin{array}{l}\text { E. coli-mycobacterial shuttle vector carrying } \\
\text { a truncated pbo } A \text { gene }\end{array}$ & Lim et al. (1995) \\
\hline $\mathrm{pExp} 53$ & $\begin{array}{l}\text { pJEM11 carrying part of a } M \text {. tuberculosis erp } \\
\text { gene similar to the } M \text {. leprae } 28 \mathrm{kDa} \text { antigen } \\
\text { gene (irg) }\end{array}$ & Lim et al. (1995) \\
\hline pIPX412 & $\begin{array}{l}\text { pBluescriptII KS - vector carrying the full- } \\
\text { length } M . \text { tuberculosis erp gene }\end{array}$ & This study \\
\hline $\mathrm{T} 74$ & $\begin{array}{l}\text { M. tuberculosis cosmid clone containing the } \\
f b p A \text { and } \text { erp genes }\end{array}$ & Poulet (1994) \\
\hline T760 & $\begin{array}{l}\text { M. tuberculosis cosmid clone containing the } \\
\text { erp gene }\end{array}$ & Poulet (1994) \\
\hline T865 & $\begin{array}{l}\text { M. tuberculosis cosmid clone containing the } \\
\text { sod } A \text { gene }\end{array}$ & Poulet (1994) \\
\hline
\end{tabular}


Wisconsin Genetics Computer Group (UWGCG) packages. The BLAST algorithm (Altschul et al., 1990) was used to search protein data bases for similaritiy.

RNA isolation and primer-extension analysis. Total RNA was isolated using the macaloid extraction procedure as previously described (Servant et al., 1994). The $M$. tuberculosis erp transcriptional start site was mapped by primer extension using the TSM2 primer (5'-TGCACAAGGACTTGCAACTGCCAGGGCGGCGAC-3') complementary to nucleotides 463-495. Unphosphorylated TSM-2 primer (15 pmol) was 5' labelled using T4 polynucleotide kinase (New England Biolabs) in the presence of $\left[\gamma_{-}{ }^{32} \mathrm{P}\right] \mathrm{dATP}(100 \mu \mathrm{Ci} ; 3.7 \mathrm{MBq})$, and unincorporated radioactivity was eliminated on a SEP-PAK C18 column (Waters Millipore). RNA $(10 \mu \mathrm{g})$ and labelled TSM-2 primer $(0.1 \mathrm{pmol})$ were mixed in a volume of $7 \mu$ l containing $0.05 \mathrm{M}$ Tris $/ \mathrm{HCl}(\mathrm{pH} 8.3$ ) and $0.1 \mathrm{M} \mathrm{KCl}$. The reaction mixture was incubated for $1 \mathrm{~min}$ at $94^{\circ} \mathrm{C}, 10 \mathrm{~min}$ at $65^{\circ} \mathrm{C}$ and $15 \mathrm{~min}$ on ice. The annealing mix was adjusted to $12 \mu \mathrm{l}$ by addition of $1 \mu \mathrm{l}$ of dATP, dGTP, dCTP, dTTP mix (2.5 mM each), $0.5 \mu \mathrm{l}$ (6 U) RNAsin (RNAguard, Pharmacia), $2 \cdot 2 \mu \mathrm{l} 5 \times$ reverse transcriptase buffer $[0.25 \mathrm{M}$ Tris $/ \mathrm{HCl}(\mathrm{pH} 8.3), 0.2 \mathrm{M} \mathrm{KCl}, 0.036 \mathrm{M}$ magnesium acetate, $0.01 \mathrm{M}$ dithiothreitol], $0.8 \mu \mathrm{l}$ diethyl pyrocarbonate-treated $\mathrm{H}_{2} \mathrm{O}$ and $0.5 \mu \mathrm{l}$ avian myeloblastosis virus reverse transcriptase (Boehringer Mannheim). Reverse transcription was performed for $45 \mathrm{~min}$ at $42{ }^{\circ} \mathrm{C}$ and stopped by addition of $5 \mu \mathrm{l} \mathrm{T} 7$ sequencing kit stop buffer. Primer extension mixtures were electrophoresed in $6 \%$ polyacrylamide gels containing $8 \mathrm{M}$ urea, in comparison with a sequence ladder of the erp gene generated using the TSM-2 oligonucleotide, and then analysed by autoradiography.

\section{RESULTS}

\section{A single copy of erp is present in the genome of M. tuberculosis}

Lim et al. (1995) described the construction of a plasmid vector (pJEM11) allowing gene fusions between a truncated $p_{0} A$ gene and mycobacterial genomic DNA fragments. A $M$. tuberculosis DNA pho $A$ fusion library was constructed and expressed in M. smegmatis. pExp53 (Fig. 1 ) is the plasmid harboured by one of the $\mathrm{PhoA}^{+}$clones selected from this library. Detection of enzymically active PhoA protein indicated that the pExp53 insert contains functional expression and exportation signals. Restriction analysis showed that pExp53 carries a $2 \mathrm{~kb}$ insert, and its sequence was partially determined. It contained a $211 \mathrm{nt}$

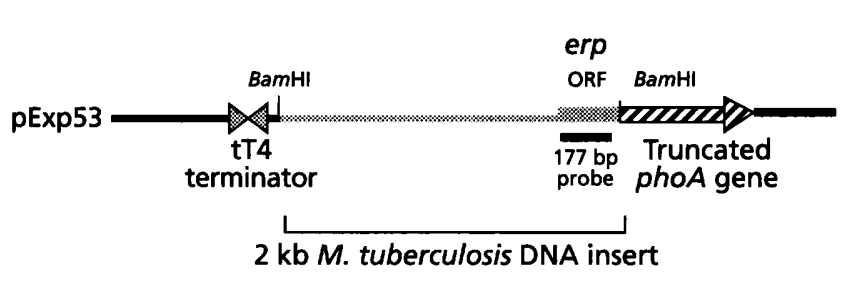

Fig. 1. Schematic diagram of pExp53. This plasmid is an E. colimycobacteria shuttle replicon (ori E. coli/ori mycobacterium) and carries the aph gene conferring resistance to kanamycin. It contains a $2 \mathrm{~kb} M$. tuberculosis DNA insert (light grey) fused to the truncated alkaline phosphatase (phoA) gene (striped). The $177 \mathrm{bp}$ PCR fragment used as a probe in this study is underlined.

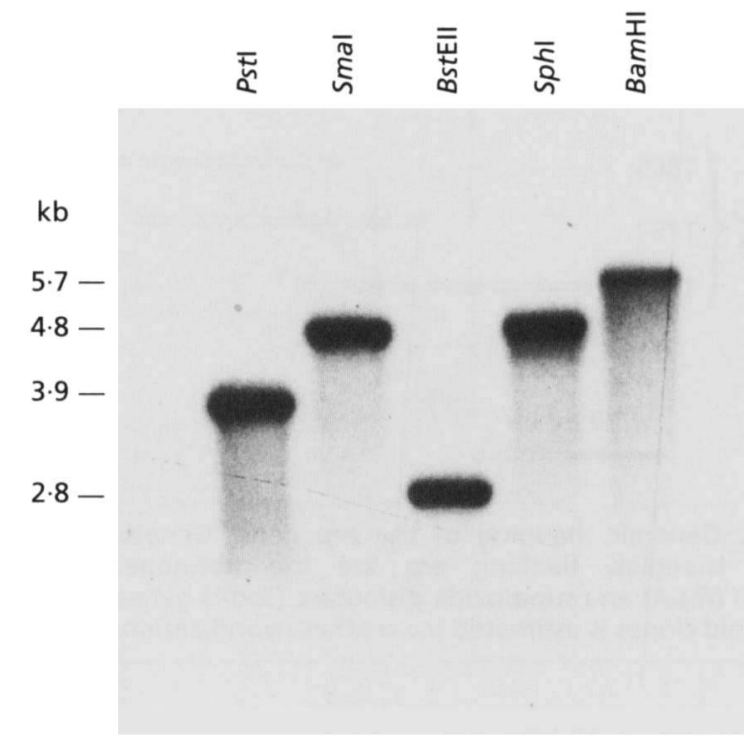

Fig. 2. Southern blot analysis using a probe derived from pExp53. Blot of $M$. tuberculosis genomic DNA digested with five different restriction enzymes and hybridized with the $177 \mathrm{bp}$ erp PCR fragment.

ORF fused in-frame with $p h o A$, exhibiting both nucleotide $(77 \%)$ and deduced peptide $(68 \%)$ sequence similarities with the $M$. leprae irg gene encoding a $28 \mathrm{kDa}$ protein antigen (Cherayil \& Young, 1987). The presence of the ORF in the $M$. tuberculosis genome was confirmed by Southern blot analysis. A $177 \mathrm{bp}$ PCR fragment corresponding to nt 23-200 of the pExp53 plasmid was used as the probe. The genomic DNA from $M$. tuberculosis $\mathrm{Mt103}$, the clinical isolate used for constructing the PhoA fusion library, was digested with five restriction enzymes chosen because they do not cut within the probe sequence. A single hybridization signal ranging from 2.8 to $6 \mathrm{~kb}$ was detected for each of the enzymes tested (Fig. 2), suggesting that erp is present in a single copy in the genome of $M$. tuberculosis.

\section{Cloning and genomic mapping of erp}

To isolate the full-length $\operatorname{erp}$ gene, a plasmid library, with $M$. tuberculosis DNA Pst I inserts of $2-6 \mathrm{~kb}$, was constructed and screened with the $177 \mathrm{bp}$ erp probe. Five strongly hybridizing transformants were isolated and restriction analyses of their plasmid DNA content indicated that all carried an identical $4.1 \mathrm{~kb}$ insert. One of them, pIPX412, was used for further studies. To map the $M$. tuberculosis erp locus with respect to other genomic markers, hybridization screening of an ordered $M$. tuberculosis cosmid library was performed with labelled pIPX412. Three overlapping cosmids hybridized with the erp probe (Fig. 3). The M. tuberculosis erp gene was thus mapped to roughly $10 \mathrm{~kb}$ from the $f b p A$ gene encoding the fibronectin-binding protein $\mathrm{A}$ from the antigen 85 complex (Wiker \& Harboe, 1992), and about $30 \mathrm{~kb}$ from the sod $A$ gene encoding the superoxide dismutase (Zhang et al., 1991). 


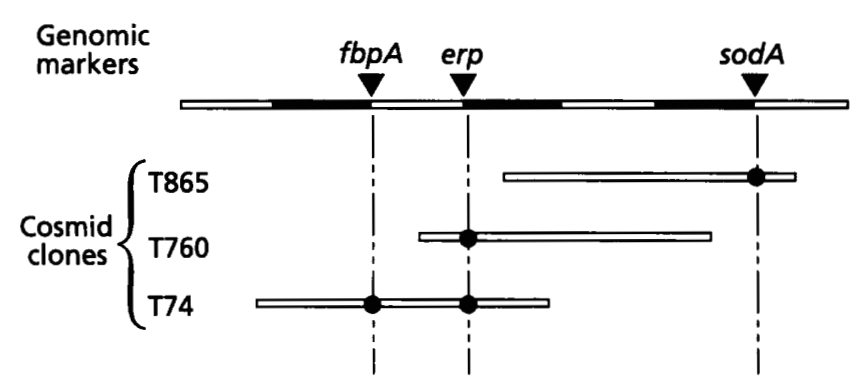

$20 \pm 4 k b$

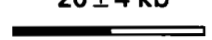

Fig. 3. Genomic mapping of the erp gene. Genetic markers (black triangles) flanking erp are the fibrinogen-binding protein $(f b p A)$ and superoxide dismutase $(\operatorname{sod} A)$ genes. The size of cosmid clones is estimated from other hybridization results.

\section{erp encodes a $28 \mathrm{kDa}$ polypeptide precursor with characteristic tandem repeats}

The nucleotide sequence of a 1536 bp region covering the $M$. tuberculosis erp gene, and the deduced amino acid sequence of the erp coding region are shown in Fig. 4. A 852 bp ORF starting with a potential GTG initiation codon at position 418 includes the ORF fused in-frame to pbo $A$ in pExp53. There is a potential Shine-Dalgarno motif (GAGGAG) at position -7 upstream of this GTG codon. This ORF ends with a TAA stop codon in position 1270 and potentially encodes a 284 amino acid polypeptide precursor with a calculated molecular mass of $27.6 \mathrm{kDa}$. The first $22 \mathrm{~N}$-terminal amino acids exhibit structural similarities with signal sequences of exported proteins (Izard \& Kendall, 1994; Pugsley, 1993). The putative site of cleavage by signal peptidase is indicated with an arrow in Fig. 4. The degree of sequence identity between M. tuberculosis erp and M. leprae irg is $64 \%$ at the nucleotide level and $60 \%$ at the peptide level.

The central region of the predicted $M$. tuberculosis $28 \mathrm{kDa}$ protein contains two sets of six tandem repeats of five amino acids based on the motif $P(G / A) L T S$. The positions 1, 3 and 5 of this motif are the most conserved, particularly in the first set of repeats, from residue 92 to 125 of the predicted peptide sequence. The second set of repeats, from residue 144 to 173 , is more degenerate. The functional significance of these repeats is unknown. Interestingly, matrix alignment indicated that these repeats are absent from the published $M$. leprae erp gene product which contains only one copy of the PGLTS motif (data not shown). Therefore the conservation of these repeats between various $M$. tuberculosis isolates was investigated. A $539 \mathrm{bp}$ DNA fragment, encompassing the two repeated domains, was amplified from ten epidemiologically and geographically unrelated $M$. tuberculosis isolates. Both RFLP analysis and partial DNA sequencing (data not shown) indicated that the number and the sequence of these repeats was well conserved in all the isolates tested.

Based on the Kyte-Doolittle plot, an hypothetical organization of the $M$. tuberculosis erp gene product is proposed in Fig. 5. In addition to the $\mathrm{N}$-terminal region corresponding to the predicted signal peptide, there is a C-terminal hydrophobic region. This region may anchor the protein in the cytoplasmic membrane or interact with other hydrophobic surface components. A stretch of four glycine residues upstream of this hydrophobic region could give flexibility to the protein.

\section{erp is present in the genome of other mycobacteria of the $M$. tuberculosis complex}

The M. tuberculosis erp genomic region covered by the $177 \mathrm{bp}$ PCR fragment probe is similar (74\% identity) to the corresponding $M$. leprae irg gene sequence, although these two species differ markedly in their $G+C$ content. We used the same probe for investigating the distribution of erp homologues among other mycobacteria. Genomic DNA of 13 mycobacterial species was digested with Pst $\mathrm{I}$, and analysed by Southern blotting (Fig. 6). At high stringency the probe hybridized specifically with the genomic DNA of bacteria belonging to the $M$. tuberculosis complex (Fig. 6b). At low stringency, a much weaker signal was also observed with DNA from $M$. avium, Mycobacterium gordonae and Mycobacterium scrofulaceum (Fig. 6a). This may correspond to hybridizations with sequences unrelated to erp, perhaps due to the high $\mathrm{G}+\mathrm{C}$ content of both the mycobacterial genomic DNA and the probe. Anyhow, hybridization signals were detected only with genomic DNA of slow-growing mycobacterial species.

\section{Characterization of the $M$. tuberculosis erp transcriptional start site}

The $M$. tuberculosis erp transcriptional start site was investigated by primer-extension analysis using RNA extracted from untransformed $M$. smegmatis $\mathrm{mc}^{2} 155$ or from strains carrying either $\mathrm{pExp} 53$ or the control pJEM11 vector (Fig. 7). A single start, located $93 \mathrm{nt}$ upstream of the GTG start codon (Fig. 4) was identified with the construct pExp53 but not with the control plasmid or untransformed bacteria. The predicted erp -10 box (TACCAT) shares some sequence similarities with the E. coli $\left(\sigma^{70}\right)$ and Bacillus subtilis $\left(\sigma^{\mathrm{A}}\right)$ consensus (TATAAT) (Moran, 1993), whereas the corresponding erp -35 box (TCT $\underline{A} G T)$ is more atypical in this respect (ITG $\underline{A C A})$.

Dale \& Patki (1990) suggested that a putative iron box may control the expression of the $M$. leprae irg gene. We found a similar motif upstream of the $M$. tuberculosis erp ORF, which overlaps with the predicted -35 box (Fig. 4). This observation is compatible with $M$. tuberculosis erp expression being regulated by iron.

\section{DISCUSSION}

The adaptation to $M$. tuberculosis of the pho $A$ methodology for identification of exported proteins was recently described by Lim et al. (1995). This methodology relies on a plasmid vector and thus can identify genes the disruption of which would be lethal for the bacterium. In the present 
CGGCTTCGGAATAGGCATTGCCCCCGATGTGCGGGCGCCGCTCGAGGACGAGCACGCGCTTGTCGAGTTGGGTEGCCACGC 81 GCTCGGCAATCGTCAGGCCGAAGAATCCTGAGCCGACGACGAAAAGGTCAAAACGAGCGGTCATCGGTTGCATAGOGTAAC 162 CGACCTTGCTGGCAAAACCCGATITGGCAGCTCGTGGCGGTCATGGCCCGAACEGCTTTCACCGCAGOTECGCATGCCCGA 243

CCAGTGTGGTTGGCCGGAGGTCGTPTGGTCGCGATTGCCTCACGATTCGATATAACCACLCLEOLCACATCAACCACACTC 324 $-35$

GLaCCatCGAGCGËGTGGGTTCATGCCATGCACTCGCGACCGCGGGAGCCGGCGAACCCGGCGCCACACATAATCCAGATT 405 $-10+1$

GAGGAGACTTCCGTGCCGAACCGACGCCGACGCAAGCTCTCGACAGCCATGAGCGCGGTCGCCGCCCTGGCAGTTGCAAGT 486

$\begin{array}{lllllllllllllllllllllllll}1 & \text { RBS } & M & \mathbf{P} & \mathbf{N} & \mathbf{R} & \mathbf{R} & \mathbf{R} & \mathbf{R} & \mathbf{K} & \mathbf{L} & \mathbf{S} & \mathbf{T} & \mathbf{A} & \mathbf{M} & \mathbf{S} & \mathbf{A} & \mathbf{V} & \mathbf{A} & \mathbf{A} & \mathbf{L} & \mathbf{A} & \mathbf{V} & \mathbf{A} \downarrow \mathbf{S}\end{array}$

CCTTGTGCATATTTTCTTGTCTACGAATCAACCGAAACGACCGAGCGCCCGAGCACCATGAATTCAAGCAGGCGGCGGTG 567

$\begin{array}{lllllllllllllllllllllllllll}\mathbf{P} & \mathbf{C} & \mathbf{A} & \mathbf{Y} & \mathbf{F} & \text { L } & \mathbf{V} & \mathbf{Y} & \mathbf{E} & \mathbf{S} & \mathbf{T} & \mathbf{E} & \mathbf{T} & \mathbf{T} & \mathbf{E} & \mathbf{R} & \mathbf{P} & \mathbf{E} & \mathbf{H} & \mathbf{H} & \mathbf{E} & \mathbf{F} & \mathbf{K} & \mathbf{Q} & \mathbf{A} & \mathbf{A} & \mathbf{V}\end{array}$

TTGACCGACCTGCCCGGCGAGCTGATGTCCGCGCTATCGCAGGGGTTGTCCCAGTTCGGGATCAACATACCGCCGGTGCCC 648

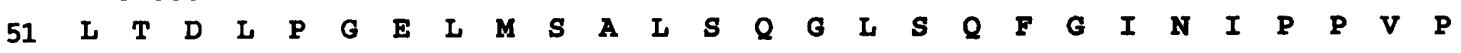

AGCCTGACCGGGAGCGGCGATGCCAGCACGGGTCTAACCGGTCCTGGCCTGACTAGTCCGGGATTGACCAGCCCGGGATTG 729

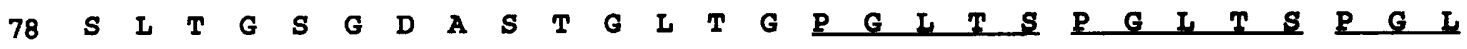

ACCAGCCCGGGCCTCACCGACCCTGCCCTTACCAGTCCGGGCCTGACGCCAACCCTGCCCGGATCACTCGCCGCGCCCGGC 810

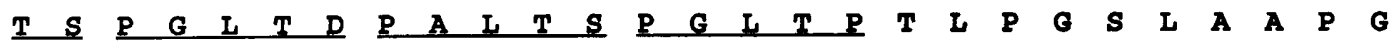

ACCACCCTGGCGCCAACGCCCGGCGTGGGGGCCAATCCGGCGCTCACCAACCCCGCGCTGACCAGCCCGACCGGGGCGACG 891

$\begin{array}{llllllllllllllllllllllllllll}132 & T & T & L & A & P & T & P & G & V & G & A & N & P & A & L & T & N & P & A & I & T & S & P & T & G & A & T\end{array}$

CCGGGATTGACCAGCCCGACGGGTPTGGATCCCGCGCTGGOCGGCGCCAACGAAATCCCGATTACGACGCCGGTCGGATTG 972

$\begin{array}{llllllllllllllllllllllllllllll}159 & P & G & L & T & S & P & T & G & \text { L } & \text { D } & \text { P } & \text { A } & \text { L } & G & G & \text { A } & \text { N } & \text { E } & \text { I } & \text { P } & \text { I } & \text { T } & \text { T } & \text { P } & \text { V } & G & \text { L }\end{array}$

GATCCCGGGGCTGACGGCACCTATCCGATCCTCGGTGATCCAACACTGGGGACCATACCGAGCAGCCCCGCCACCACCTCC 1053

$\begin{array}{lllllllllllllllllllllllllllll}186 & \mathbf{D} & \mathbf{P} & \mathbf{G} & \mathbf{A} & \mathbf{D} & \mathbf{G} & \mathbf{T} & \mathbf{Y} & \mathbf{P} & \mathbf{I} & \mathbf{L} & \mathbf{G} & \mathbf{D} & \mathbf{P} & \mathbf{T} & \mathbf{L} & \mathbf{G} & \mathbf{T} & \mathbf{I} & \mathbf{P} & \mathbf{S} & \mathbf{S} & \mathbf{P} & \mathbf{A} & \mathbf{T} & \mathbf{T} & \mathbf{S}\end{array}$

ACCGGCGGCGCGGTCTCGTCAACGACGTGATGCAGGTGGCCAACGAGTTGGGCGCAGTCAGGCTATCGACCTGCTAAAA 1134

$\begin{array}{lllllllllllllllllllllllllllll}213 & \text { T } & G & G & G & G & \text { L } & \text { V } & \text { N } & \text { D } & \text { V } & \text { M } & \text { Q } & \text { V } & \text { A } & \text { N } & \text { E } & \text { L } & \text { G } & \text { A } & \text { S } & \text { Q } & \text { A } & \text { I } & \text { D } & \text { I } & \text { I } & \text { K }\end{array}$

GGTGTGCTAATGCCGTCGATCATGCAGGCCGTCCAGAATGGCGGCGCGGTCGCGCCGGCAGCCAGCCCGCCGGTCCCGCCC 1215

$\begin{array}{llllllllllllllllllllllllllll}240 & \text { G } & \text { V } & \text { L } & \text { M } & \text { P } & \text { S } & \text { I } & \text { M } & \mathbf{Q} & \text { A } & \text { V } & \mathbf{Q} & \text { N } & \text { G } & \text { G } & \text { A } & \text { V } & \text { A } & \text { P } & \text { A } & \text { A } & \text { S } & \text { P } & \text { P } & \text { V } & \text { P } & \text { P }\end{array}$

ATCCCCGCGGCCGCGGCGGTGCCACCGACGGACCCAATCACCGTGCCOGTCGCCTAAGCCCCGGGTCGGCCGAAACGCAC 1296

$\begin{array}{lllllllllllllllllll}267 & \text { I } & \text { P } & \text { A } & \text { A } & \text { A } & \text { A } & \text { V } & \text { P } & \text { P } & \text { T } & \text { D } & \text { P } & \text { I } & \text { T } & \text { V } & \text { P } & \text { V } & \text { A }\end{array}$

CCGCGGCCAAGGCGTCGTTCATTGCTPCGGCCCGTCACAATPACTCGCCTAAGGOTCGCTAGGTGTTCTCGAGAGTHTAT 1377 CGCACCGATTCCGTGTCGTCTCATTAATACCAATAGAAACACACGTAACATCACCTEOTOCCETCCCGCACCCGCGCGCCG 1455 ACGACGCTGCTCACCGCGATGGCAGCGACCGTCGTCATCGTCGCGTGGATAGCGAATCOTCCACCCGCCAGCTCCCAT

Fig. 4. Nucleotide sequence of the $M$. tuberculosis erp gene and deduced amino acid sequence. The nucleotide sequence corresponding to a putative iron box is indicated by black stars. The mapped transcriptional start site, together with the predicted -10 and -35 boxes are represented in lower case letters. The potential RBS is underlined. Single-letter amino acid code is used. A potential signal peptidase cleavage site is indicated with an arrow. Repeated amino acid stretches in the central part of the erp gene product are underlined.

report, the characterization of the M. tuberculosis erp gene which has similarity with a $M$. leprae gene (irg) encoding a $28 \mathrm{kDa}$ protein antigen is described. $M$. tuberculosis erp contains repetitive structures conserved among isolates and a putative iron box is located close to the mapped transcriptional start site.
The organization of the $M$. tuberculosis erp gene is similar to that of the $M$. leprae counterpart (Cherayil \& Young, 1987). The C-terminal hydrophobic region could be involved in membrane anchorage of the protein (Davis $e t$ al., 1985). However, the $M$. tuberculosis erp gene product is longer due to the presence of additional residues (amino 


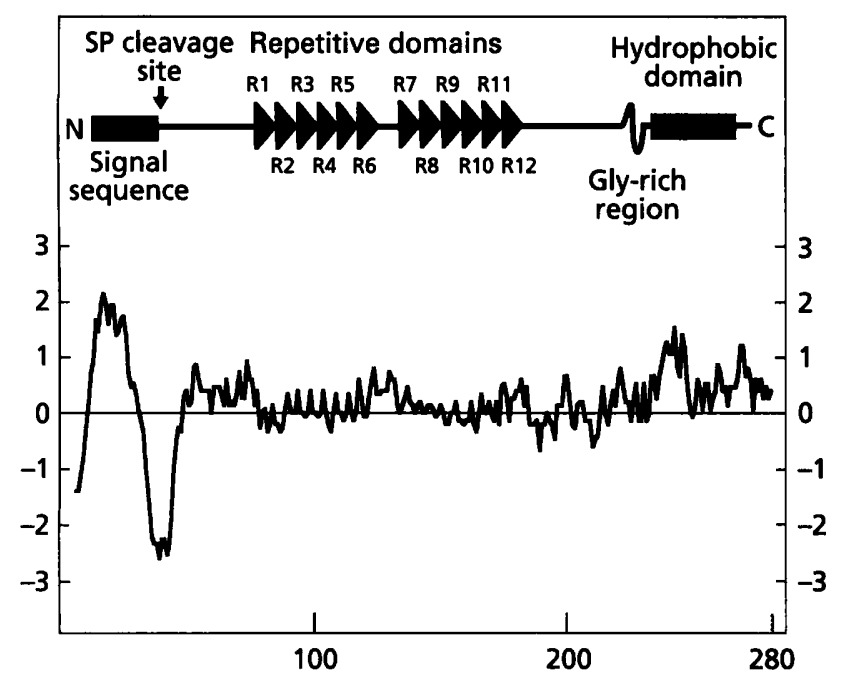

Fig. 5. Kyte-Doolittle plot and predicted domain organization of the erp gene product. Plots above the line indicate a hydrophobic nature. Tandem repeats numbered from R1 to R12 are represented as black arrowheads.

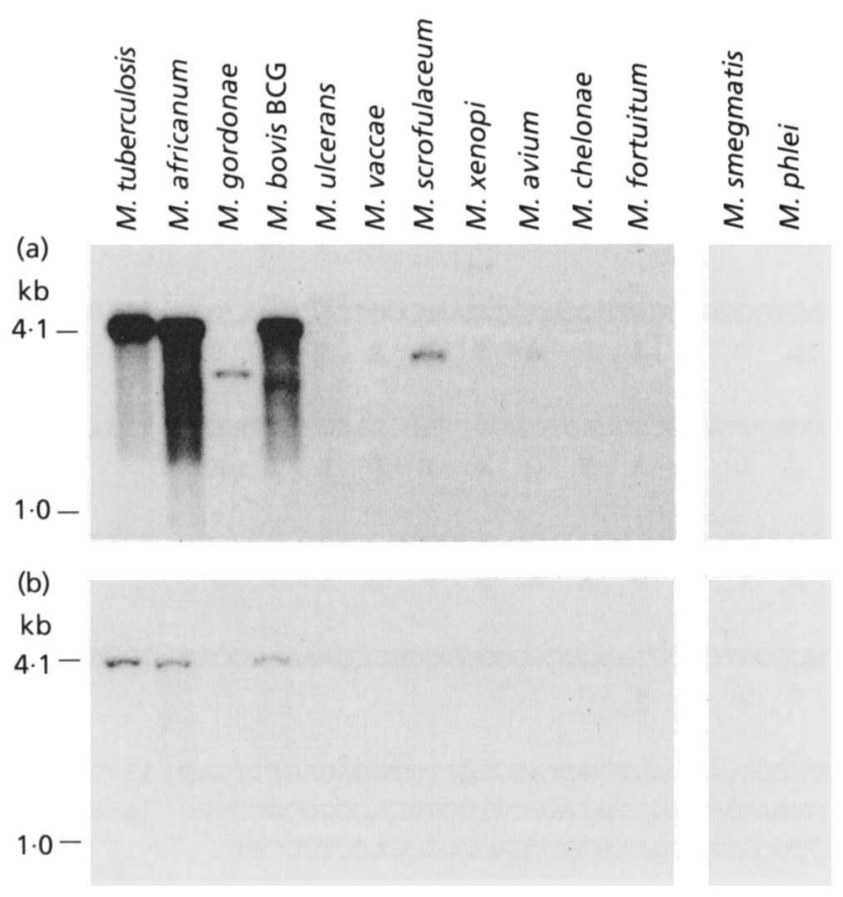

Fig. 6. Distribution of the erp-like gene sequences among mycobacteria. Mycobacterial genomic DNAs were digested to completion with Pstl and analysed by Southern blotting under (a) low or (b) high stringency conditions.

acids 126-177) encompassing the second set of repeats, and encodes a predicted $28 \mathrm{kDa}$ protein precursor. The molecular mass calculated from the published $M$. leprae ' 28 ' $\mathrm{kDa}$ antigen precursor sequence is actually $24 \mathrm{kDa}$. The presence of tandemly repeated sequences is a striking structural feature of many Gram-positive cell-wall-

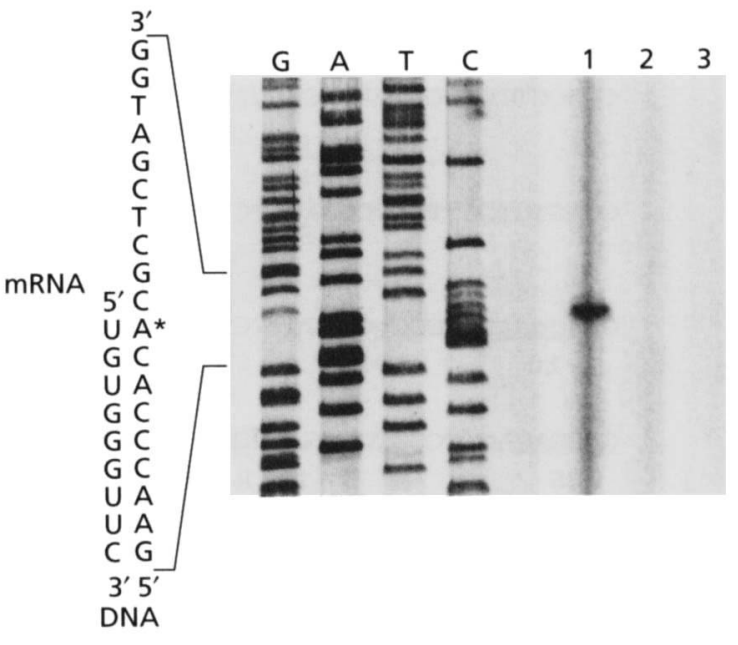

Fig. 7. Mapping of the erp transcriptional start site by primer extension using the TSM-2 oligonucleotide primer. Lanes 1-3 correspond respectively to primer-extension reactions performed with RNA extracted from $M$. smegmatis(pExp53), $M$. smegmatis(pJEM11) and non-transformed $M$. smegmatis. The end of the primer-extension product is indicated by a star.

associated proteins (Kehoe, 1994). Tandem repeats can vary in length from two to more than 100 residues. The mechanisms by which they are produced are not clearly understood. However, duplication and deletion of these repeats are frequent events. For instance, in group A streptococcal $M$ proteins, the number of copies of tandem repeats differs among isolates (Fischetti et al., 1986). Here, the number and the sequence of erp repeats was found to be conserved among $M$. tuberculosis isolates of various origins, and thus is not a source of polymorphism. They may thus be important for the function of the erp gene product.

Cell-wall-associated proteins with tandem repeats have been associated with binding domains for other proteins or polysaccharides (Talay et al., 1994; Westerlund \& Korhoen, 1993). In the serotype $5 \mathrm{M}$ protein, the binding site for fibrinogen has been localized within the group B repeats. IgG Fc-binding proteins such as protein A, protein $G$ and several group A streptococcal $\mathrm{emm}$-like proteins also share the same general organization with an $\mathrm{N}$-terminal signal sequence, tandemly repeated sequences and a hydrophobic charged C-terminal tail (Kehoe, 1994). Genes encoding wall-associated fibronectin-binding proteins have been cloned from Staphylococcus aureus, Streptococcus pyogenes, and Streptococcus dysgalactiae (Flock et al., 1987; Hanski \& Caparon, 1992; Lindgren et al., 1992; Talay et al., 1991). They contain a number of different types of tandemly repeated sequences. In mycobacteria, at least two other genes in addition to $M$. tuberculosis erp, have been reported to potentially encode proteins with tandem repeats: the $M$. leprae proline-rich antigen ( pra) gene (Thole et al., 1990), and an ORF found next to the $M$. tuberculosis $65 \mathrm{kDa}$ antigen gene (Shinnick, 1987). However, no function has yet been ascribed to these repeats.

Localization of proteins at the bacterial cell surface is the 
result of a complex targeting process, involving exportation and interaction with the peptidoglycan network. In most cases, cell-wall-associated proteins of Gram-positive bacteria have a characteristic hexapeptide motif LPXTGX, followed by the putative region of membrane anchorage (Fischetti et al., 1990). This motif has recently been shown to be required for covalent linkage of the peptide chain to the peptidoglycan (Navarre \& Schneewind, 1994). This signature is absent from the M. tuberculosis Erp protein. However, the Listeria monocytogenes gene inlB, encoding the cell-wall-associated internalin $\mathrm{B}$, is also devoid of the LPXTGX motif (Gaillard et al., 1991).

Iron has been shown to be involved in the regulation of virulence genes in many pathogenic bacteria (for reviews see Griffith, 1991, and Litwin \& Calderwood, 1993). These regulatory mechanisms rely on a bacterial repressor protein controlling gene expression at the transcriptional level. In the presence of iron, this repressor interacts with a target DNA sequence referred to as the iron box, and blocks gene expression. Under iron-limited conditions, such as those existing during growth within mammalian tissues or cells, repression is relieved and the expression of iron-regulated genes is induced. Based on nucleotide sequence similarities, Dale \& Patki (1990) have postulated the existence of such a putative iron box regulating the expression of the $M$. leprae irg gene. In the present paper, a similar motif overlapping the predicted -35 box of the M. tuberculosis erp gene was found. This result might be considered to support there being iron regulation of the erp gene. However, when the PhoA activity of the Erp-PhoA protein fusion was assayed in cell extracts of $M$. smegmatis ( $\mathrm{pExp} 53)$ grown under iron-sufficient or iron-limited conditions, no increase in Erp-PhoA expression was detected under iron-limited conditions (data not shown). Determining whether or not erp is ironregulated will require a detailed analysis of its expression in $M$. tuberculosis.

It is known for other iron boxes described so far that they are preferentially located between the -10 and -35 regions. Additionally, both $M$. leprae irg and $M$. tuberculosis erp putative iron box motifs share similarities with the consensus sequence defined for binding the Gramnegative Fur repressor (Litwin \& Calderwood, 1993). Recently, Fiss et al. (1994) cloned and functionally characterized an iron box involved in the regulation of the ferric exochelin biosynthetic pathway of $M$. smegmatis. Interestingly, the sequence fits with the consensus for the Gram-positive DtxR repressor binding site (Tao et al., 1994). Collectively, these observations raise the possibility that iron may regulate gene expression by different mechanisms in mycobacteria.

\section{ACKNOWLEDGEMENTS}

We thank P. Cossart, S. Cole and A. Kolb for very helpful discussions. We are grateful to G. Torrea and M. Picardeau for the kind gift of mycobacterial genomic DNAs, and to J.-M. Reyrat and A. Edelman for critical reading of the manuscript. F.-X.B. and E.M.L are recipients of the Agence Nationale de la Recherche sur le SIDA (ANRS) and of the Ministère de l'Enseignement Supérieur et de la Recherche, respectively. This work was supported by the UNDP/World Bank/WHO Special Program for Research and Training in Tropical Diseases and by an EEC grant (BIO-CT92-0520)

\section{REFERENCES}

Altschul, S. F., Gish, W., Miller, W., Myers, E. W. \& Lipman, D. J. (1990). Basic local alignment search tool. J Mol Biol 215, 403-410.

Cherayil, B. J. \& Young, R. A. (1987). A $28 \mathrm{kDa}$ protein from Mycobacterium leprae is a target of the human antibody response in lepromatous leprosy. J Immunol 141, 4370-4375.

Dale, J. W. \& Patki, A. (1990). Mycobacterial gene expression and regulation. In Molecular Biology of the Mycobacteria, pp. 173-198. Edited by J. J. McFadden. Guildford: Surrey University Press.

Davis, N. G., Boeke, J. D. \& Model, P. (1985). Fine structure of a membrane anchor domain. J Mol Biol 181, 111-121.

Fiss, E. H., Yu, S. \& Jacobs, W. R., Jr (1994). Identification of genes involved in the sequestration of iron in mycobacteria: the ferric exochelin biosynthetic and uptake pathways. Mol Microbiol 14, 557-569.

Fischetti, V. A., Jarymowycz, M., Jones, K. F. \& Scott, J. R. (1986). Streptococcal M protein size mutants occur at high frequency within a single strain. $J$ Exp Med 164, 971-980.

Fischetti, V. A., Pancholi, v. \& Schneewind, O. (1990). Conservation of a hexapeptide sequence in the anchor region of surface proteins from Gram-positive cocci. Mol Microbiol 4, 1603-1605.

Flock, J.-l., Fröman, G., Jonsson, K., Guss, B., Signäs, C., Nilsson, B., Raucci, G., Hobk, M., Wadstrom, T. \& Lindberg, M. (1987). Cloning and expression of the gene for a fibronectin-binding protein from Staphylococcus aureus. EMBO J 6, 2351-2357.

Gaillard, J.-L., Berche, P., Frehel, C., Gouin, E. \& Cossart, P. (1991). Entry of $L$. monocytogenes into cells is mediated by internalin, a repeat protein reminiscent of surface antigens from Gram-positive cocci. Cell 65, 1127-1141.

Griffith, E. (1991). Environmental regulation of bacterial virulence. Implications for vaccine design and production. Trends Biotechnol 9 , 309-315.

Hanski, E. \& Caparon, M. (1992). Protein F, a fibronectin-binding protein, is an adhesin of the group A streptococcus Streptococcus pyogenes. Proc Natl Acad Sci USA 89, 6172-6176.

Hoffman, C. S. \& Wright, A. (1985). Fusions of secreted proteins to alkaline phosphatase: an approach for studying protein secretion. Proc Natl Acad Sci US A 82, 5107-5111.

Isberg, R. R., Voorhis, D. L. \& Falkow, S. (1987). Identification of invasin: a protein that allows enteric bacteria to penetrate cultured mammalian cells. Cell 50, 769-778.

Izard, J. W. \& Kendall, D. A. (1994). Signal peptides: exquisitely designed transport promoters. Mol Microbiol 13, 765-773.

Kehoe, M. A. (1994). Cell wall-associated proteins in Gram-positive bacteria. In Bacterial Cell Wall, pp. 217-261. Edited by J.-M. Ghuysen \& R. Hakenbek. Amsterdam: Elsevier Science.

Lim, E. M., Rauzier, J., Timm, J., Torrea, G., Murray, A., Gicquel, B. \& Portnor, D. (1995). Identification of Mycobacterium tuberculosis DNA sequences encoding exported proteins, using pho $A$ gene fusions. J Bacteriol 177, 59-65.

Lindgren, P.-E., Speziale, P., McGavin, M., Monstein, H.-J., Hobk, M., Visai, L., Kostiainen, T., Bozzini, S. \& Lindberg, M. (1992). Cloning and expression of two different genes from Streptococcus dysgalactiae encoding fibronectin receptors. $J$ Biol Chem 267, 1924-1931. 
Litwin, C. M. \& Calderwood, S. B. (1993). Role of iron in the regulation of virulence genes. Clin Microbiol Rev 6, 137-149.

Manoil, C., Mekalanos, J. J. \& Beckwith, J. (1990). Alkaline phosphatase fusions: sensors of subcellular location. J Bacteriol 172, $515-518$

Miller, J. H. (1972). Experiments in Molecular Genetics. Cold Spring Harbor, NY: Cold Spring Harbor Laboratory.

Moran, C. P., Jr (1993). RNA polymerase and transcription factors. In Bacillus subtilis and Other Gram-Positive Bacteria: Biochemistry, Physiology, and Molecular Genetics, pp. 653-667. Edited by A. L. Sonenshein, J. A. Hoch \& R. Losick. Washington, DC: American Society for Microbiology.

Navarre, W. W. \& Schneewind, O. (1994). Proteolytic cleavage and cell wall anchoring at the LPXTGX motif on surface proteins in Gram-positive bacteria. Mol Microbiol 14, 115-121.

Poulet, S. (1994). Organisation génomique de Mycobacterium tuberculosis et épidémiologie moléculaire de la tuberculose. $\mathrm{PhD}$ thesis, Université Paris VI.

Pugsley, A. P. (1993). The complete general secretory pathway in Gram-negative bacteria. Microbiol Rev 57, 50-108.

Sambrook, J., Fritsch, E. F. \& Maniatis, T. (1989). Molecular Cloning: a Laboratory Manual, 2nd edn. Cold Spring Harbor, NY: Cold Spring Harbor Laboratory.

Sanger, F., Nicklen, S. \& Coulson, A. R. (1977). DNA sequencing with chain-terminating inhibitors. Proc Natl Acad Sci USA 74, 5463-5467.

Servant, P., Thompson, C. J. \& Mazodier, P. (1994). Posttranscriptional regulation of the groEL1 gene of Streptomyces albus. Mol Microbiol 12, 423-432.

Shinnick, T. M. (1987). The 65-kilodalton antigen of Mycobacterium tuberculosis. J Bacteriol 169, 1080-1088.

Short, J. M., Fernandez, J. M., Sorge, J. A. \& Huse, W. D. (1988). $\lambda$ ZAP: a bacteriophage expression vector with in vivo excision properties. Nucleic Acids Res 15, 7583-7600.

Snapper, S. B., Melton, R. E., Mustapha, S., Kieser, T. \& Jacobs, W. R., Jr (1990). Isolation and characterization of efficient plasmid transformation mutant of Mycobacterium smegmatis. Mol Microbiol11, 1911-1919.

Talay, S. R., Ehrenfeld, E., Chatwal, G. S. \& Timmis, K. N. (1991). Expression of the fibronectin-binding components of Streptococcus pyogenes in Escherichia coli demonstrates that they are proteins. Mol Microbiol 5, 1727-1734.

Talay, S. R., Valentin-Weigant, P., Timmis, K. N. \& Chatwal, G. S. (1994). Domain structure and conserved epitopes of Sfb protein, the fibronectin-binding adhesin of Streptococcus pyogenes. Mol Microbiol 13, 531-539.

Tao, X., Schiering, N., Zeng, H.-Y., Ringe, D. \& Murphy, J. R. (1994). Iron, DtxR, and the regulation of diphtheria toxin expression. Mol Microbiol 14, 191-197.

Thole, J. E. R., Stabel, L. F. E. M., Suykerbuyk, M. E. G., De Wit, M. Y. L., Klatser, P. R., Kolk, A. H. J. \& Hartskeerl, R. A. (1990). A major immunogenic 36000-molecular-weight antigen from Mycobacterium leprae contains an immunoreactive region of prolinerich repeats. Infect Immun 58, 80-87.

Timm, J., Perilli, M. G., Duez, C., Trias, J., Orefici, G., Fattorini, L., Amicosante, G., Oratore, A., Joris, B., Frère, J. M., Pugsley, A. P. \& Gicquel, B. (1994). Transcription and expression analysis, using lac $Z$ and $p h o A$ gene fusions, of Mycobacterium fortuitum $\beta$-lactamase genes cloned from a natural isolate and a high level $\beta$-lactamase producer. Mol Microbiol 12, 491-504.

Westerlund, B. \& Korhoen, T. K. (1993). Bacterial proteins binding to the mammalian extracellular matrix. Mol Microbiol 9, 687-694.

Wiker, H. G. \& Harboe, M. (1992). The antigen 85 complex: a major secretion product of Mycobacterium tuberculosis. Microbiol Rev 56, 648-661.

Young, D. B., Kaufmann, S. H. E., Hermans, P. W. M. \& Thole, J. E. R. (1992). Mycobacterial protein antigens: a compilation. Mol Microbiol 6, 133-145.

Zhang, Y., Lathigra, R., Garbe, T., Catty, D. \& Young, D. (1991). Genetic analysis of superoxide dismutase, the 23 kilodalton antigen of Mycobacterium tuberculosis. Mol Microbiol 5, 381-391.

Received 5 April 1995; revised 5 May 1995; accepted 5 June 1995 